\title{
SandLife and the death of dunes: political ecology discourses from conservation to restoration in Haverdal, Sweden
}

\author{
Mikael S-O Ring ${ }^{1}$ \\ Gothenburg University, Sweden
}

\begin{abstract}
This study concerns narratives and practices developed within landscape management in a Natura 2000 area in the south-west of Sweden. This European Union-funded project shifted focus from morphological and passive conservation management to intervening in biological management. I investigate some of the consequences of re-politicized discourses and practices during this period. I ask how a traditional policy view on conservation was handled during this change, and what role EU funding has in preserving or changing a traditional management policy for landscape conservation. The conclusions are that landscape protection is driven by political and ideological values connected with institutionalized aesthetic components that are adjusted to whatever disciplinary focus prevails at the time. However, traditional approaches are retained, excluding participatory methods and the social dimensions on landscape management. To some extent, the available EU funding leverages alignment of project goals and management, influencing landscape alteration.
\end{abstract}

Keywords: SandLife, political ecology discourses, landscape restoration and management, aesthetics, morphology and biology, EU projects

\section{Résumé}

Cette étude concerne les récits et les pratiques développés dans le cadre de la gestion du paysage dans une zone Natura 2000 au sud-ouest de la Suède. Ce projet financé par l'UE a déplacé son attention de la gestion morphologique et passive de la conservation vers une intervention dans la gestion biologique. J'étudie certaines des conséquences des discours et des pratiques repolitisés au cours de cette période. Je demande comment une vision politique traditionnelle de la conservation a été gérée pendant ce changement, et quel rôle le financement de l'UE a dans la préservation ou la modification d'une politique de gestion traditionnelle pour la conservation des paysages. Les conclusions sont que la protection du paysage est motivée par des valeurs politiques et idéologiques liées à des éléments esthétiques institutionnalisés qui sont ajustés en fonction de la discipline qui prévaut à l'époque. Cependant, les approches traditionnelles sont conservées, excluant les méthodes participatives et les dimensions sociales de la gestion du paysage. Dans une certaine mesure, les financements européens disponibles tirent parti de l'alignement des objectifs et de la gestion des projets, influençant l'altération du paysage.

Mots-clés: SandLife, discours d'écologie politique, restauration et gestion du paysage, esthétique, morphologie et biologie, projets européens

\section{Resumen}

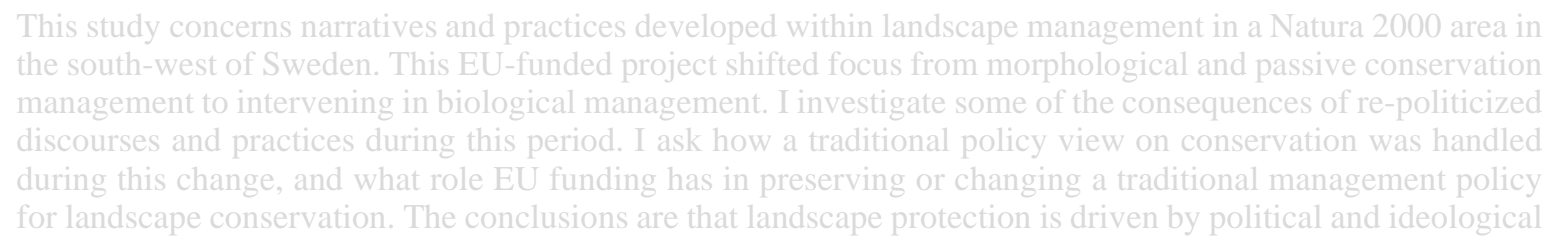

\footnotetext{
${ }^{1}$ Dr. Mikael S-O Ring, Associate Professor, Unit for Human Geography, Department of Economy and Society, School of Business, Economics and Law, University of Gothenburg, Sweden. Email: mikael.ring "at" geography.gu.se. Thankyou to a referee and journal editors.
} 


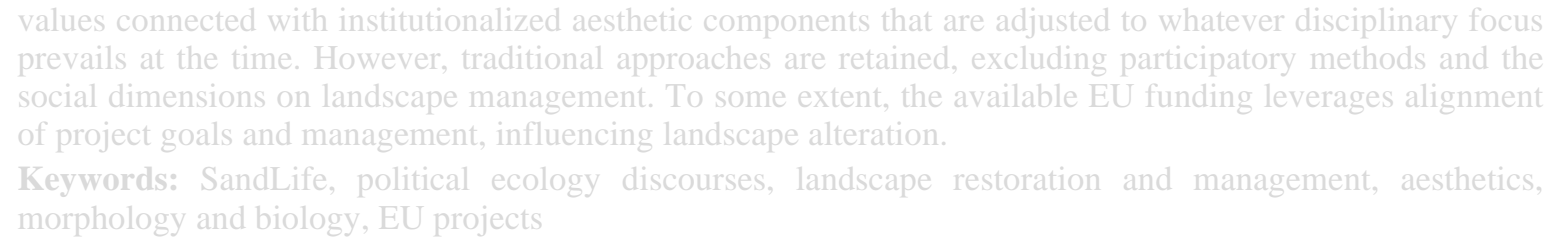

\section{Introduction}

The aim of this study is to investigate some of the consequences produced by re-politicized discourses and practices involved in landscape management, restoration and protection. The case is a Natura 2000 area in the south-west of Sweden, which underwent a shift in conservation practice from morphological to biological interventions. This raises the issue of how traditional conservation policy fares during such a change, and what role EU funding plays in this case. A specific feature of traditional planning in this landscape is the existence of a longstanding tradition of decide-announce-defend (DAD) planning procedures, which can lead to planning conflicts that consume time and energy (Breukers 2006: 43).

The case of Haverdal illustrates three themes related to landscape management, protection, conservation and restoration, and these have relevance for political ecology. Political ecology as used here relates to values, practices, narratives, discourses, representations, technologies of government and orthodoxies with environmental services that are related to a specific physical, political, social and historical context (in terms of land-use practices and values) (Robbins 2012; Rose and Miller 2010; Setten 2017). Firstly, the study situates the geographical context, which has a specific planning history and tradition related to Nordic geography and environmental governance (Benjaminsen and Robbins 2015; Benjaminsen and Svarstad 2019; Olwig 2002; Qvenild 2014; Sandberg and Jacobsson 2018; Setten 2017; Widgren 2015). Secondly, it explores a European Union (EU) restoration project which reconfigured and re-politicized the ideological views on traditional DADmanagement, where some traditional features from that approach remained unchanged. Impacts are implemented in terms of local institutionalized power relations related to knowledge, control, access, participation and definitions of privileged species in the landscape. Plants are no longer seen as pure and timeless objects removed from society, but have agency - this adds to the political dynamics that animate socionatures (Escobar 1995; 1998; Dahlberg 2015; Lorimer 2012; Nightingale 2014: 125; Setten 2017).

A third strand of political ecology is to investigate the institutionalized aesthetics that guide planners in configuring the policies and practices for landscape management. In the case, landscape management, grounded in a biogenetic biocentrism and Malthusian morphogenetic explanations, has a rationality and an ideology that sees landscapes as suffering from tourism impacts and private gardening. While these traditional views reflect a $\mathrm{DAD}$-approach and a reluctance towards participation and public engagement, receiving funding from the EU required a redirection of earlier ideas and practices for management.

The new composition of local politics and EU-program requirements re-politicized ideologies, moralities and aesthetic values, and these are investigated in this study. It is argued that political discourses are creating new linkages between social justice and a type of institutionalized activism called nature-justice, consisting of actions towards, for instance, biodiversity loss. This moral and aesthetic reasoning results in an activist configuration which allows for viewing nature in terms of access and control over resources such that actions imply an appropriation of nature that is justified by maintaining authoritative power relations (compare with Escobar 1998, and Harvey 1996). Authoritarian power can be seen as a way of claiming the territory in different seasons, thus landscape restoration and management have temporal dimensions.

\section{Theoretical and planning approaches}

It is easy to revert to established ways of seeing nature, as untouched by and separated from humans, and thus deemphasizing the workings of power, contested opinions, and discourses (Head, Saltzman, Setten and Stenseke 2017; Robbins 2012; Setten 2017: 31; Stenseke 2009; Wästfelt et al. 2012). Political rationalities are articulated with epistemological characteristics, direct conceptions of nature, and the objects governed. 
They embody accounts from the people over whom government is to be exercised (Rose and Miller 2010: 277). The politics of landscapes exist in the interface between geography and ethics (Proctor 1998; Smith 2000) and includes everyday activities and institutional decisions that are instrumental for nature. As many political ecologists have shown, discourses have power beyond the spoken or written word, and they are performative (Jonasson 2000).

The response of planners, as holders of institutional power, to any resistance to landscape projects can be a one-sided information campaign characterizing complaint as "nimbyism", and seeing this as based on people's self-interest and localism (Breukers 2006). Discourse-coalitions or 'hybrids' can reify beliefs about physical reality and thus discourse analysis can discover the co-production of a landscape (Hajer 1995; 2001; Hajer and Versteeg 2005). Management and project plans are thus emerging devices for governing and controlling socio-natures through their ideologies (Rose and Miller 2010: 275).

In most of Western Europe, including the Nordic countries, local governments now operate according to the principles of representative or indirect democracy. Citizens can thus respond to planning proposals, and local authorities decide whether to take their responses into account. Breukers (2006: 43) claims that many reactions to project proposals and management practices are negative. For decision makers, it may, therefore, be tempting not to involve citizens in the early stages of the process to avoid delays in implementation. However, blockages can be reciprocal in DAD approaches, and much energy is spent on conflicts at the announced starting points. The DAD approach assumes that citizens' knowledge of and interests in the sites are neither useful nor legitimate and that they originate in a lack of "proper" knowledge of the nature of the problem.

The use of DAD approaches in planning and project implementation also involves an epistemological and political ecology dimension related to disciplinary background and disciplinary fostering, so while natural scientists working in applied disciplines are perhaps most interested in overcoming or circumventing opposition to delivering their management goals, social researchers often focus on exploring competing aims and the knowledge that underpins disputes (Crowley, Hinchliffe and McDonald 2017). The project in this case had been debated and defended prior to 2011, and to its ending in 2018. The close linkages between EU and a local environment means that the discourses and practices involved in the project were intending to create a European identity and conformity regarding landscape planning (Widgren 2015). These intentions need to be translated and transformed into a specific practice relevant to history, planning traditions, narratives and stories.

Landscape management involves temporalities in which different ideas on nature are embedded (Head, Saltzman, Setten and Stenseke 2017). Uncertain future ecologies put explicit pressure on configurations of responsibility, whether legal or moral (ibid, p.7). The moral configuration in this case is, I suggest, defined as an institutional activist nature-justice for which men and women in the civil service are guided in producing discourses and practices that aim at protecting biological dimensions of the landscape, and in which particular aesthetic views guide the morality and justification of activities and narratives (Escobar 1998 and Harvey 1996; Santayana 1896). Also, values about nature have developed over long time periods, influencing us today. A love of mobility, freedom, speed, diversity, progress, familiarity, and a mechanistic view of nature have contributed to the acceptance some alien invasions of species (Low 2001: 37). The landscape in question has undergone several such major changes that frames it not only as a portion of space, but it is also temporally framed (Davidson and Williams 2017: 15). The most recent change involved a shift from management of morphological features (sand dune erosion) towards biological dimensions (managing insects, alien invasive-, and just foreign or non-native species). According to Setten (2017) and Qvenild and Setten (2019) the alien species debate, and its associated practices, involve material and discursive attempts to mobilize, fix and purify landscapes according to what appears to be placed in any time context without substantial argument and in what is called a random temporal species rhetoric.

People mobilize different environments, through embodied practices and institutional strategies to keep and regain control, to fix whatever is lost and to produce predictable futures (Head, Saltzman, Setten and Stenseke 2017: 4). The notion of mobility involves that fact that environments, natures and people do not stand still. In the ecological sciences, nonequilibrium ecological theory or the "new ecology" has had an impact (Davidson and Williams 2017: 22). Instead of assuming that systems are heading towards stasis, harmony and 
balance, scientists recognize that in non-equilibrium ecologies they are in flux, show stochastic change, and plants and animals display novelty and opportunism (Low 2002). Alien species show spatial and temporal mobility (Head, Saltzman, Setten and Stenseke 2017: 5).

\section{Methodology}

\section{Design and data collection}

This study used a qualitative design and was conducted through a textual analysis, and data gathered during a one-day excursion offered by the project. Texts were drawn from restoration project documents and management instructions from the County Administrative Board of Halland (CABH). ${ }^{2}$ The material consists of management documents and project descriptions from an EU project called SandLife. While project documents are written in English, management documents are written in Swedish. Quotations from the latter have been translated into English by the author. These documents do not merely reflect social realities and landscapes but also actively create these landscapes. The different documents analyzed are related intertextually and contextually (Rose 2007). The EU project helped to reorient the management of the area. It situated and reconfigured the management plans in broader intertextual contexts in relation to other EU projects. The local context, situated in Swedish planning in general, was enlarged. The local context also contains an intertextual dimension where village gossip, traditional and social media co-produce discourses about the landscape in question.

In addition to texts, the study involves a short participatory element. In 2015 I joined one of the announced excursions arranged by the SandLife project staff in Haverdal from CABH and spent about an hour following a small group of other people interested in the project and took notes during the event. The SandLife project included meetings with stakeholders, such as landowners and NGOs as well as organizing excursions in order to inform and engage the public. The project staff were said to be practitioners from CABH and natural scientists from a university in southern Sweden.

As a resident in the village of Haverdal the author has an inside perspective and access to material beyond that presented in this study. However, the insider view also affects perspective and positionality, including through a strong sense of this place. This position may have influenced all choices, from aim, questions, methods, collected material, interpretations, analysis and conclusions. My close relationship with the community also meant that the population of Haverdal was excluded from the study.

\section{Data analysis}

I used a close reading technique based on a conventional content analysis where categories are coded directly from the text (Delyser et al. 2009; Hsieh and Shannon 2005). The analysis and shaping of themes and categories were guided by how these documents produce commonalities for defining the landscape through geographical theories on socio-ecological discourses, practices, planning theory, and reasoning in terms of aesthetics.

The analysis and coding of texts involves the active production of patterns where elements of storylines and narratives are shared, differ, or are defined as significant (Hajer 1995; Rose 2007). Significance is valued in light of the aim and research questions. Interpretation involves finding the nodes where a document, a technology or a practice is "...organized to make itself persuasive" (Gill 2000: 189) and the ways in which the investigated documents structure the way a thought is formed and the way we act (or not) by that thinking (Rose 2007: 136). Documents and the participant observation revealed three narrative elements: 'geographical context', 'EU-funding', and 'aesthetic values from a planner perspective.'

${ }^{2}$ http://sandlife.se/?page_id $=785$, https://www.lansstyrelsen.se/download/18.6f456f1162f6d08f5e99cc/1526068043675/Sk\%C3\%B6tselplan\%20f\%C3\%B6 r\%20naturreservatet\%20Haverdal.pdf 


\section{Results}

Political ecology and the shaping of needs for protection in Haverdal and the Natura 2000 Area

A nature reserve (a traditionally protected area) and a Natura 2000 reserve are located next to Haverdal village, $25 \mathrm{~km}$ from Halmstad municipality in Sweden (Figure 1). The reserve is managed by the municipality, but the policies for restoration and management for it and the and Natura 2000 area are drawn up by the $\mathrm{CABH}$, a decentralized authority within the structure of the Swedish state, and the municipality of Halmstad. ${ }^{3}$ A large proportion of the houses close to the Natura 2000 area are vacation homes or belong to interests involving leisure and tourism. The local population is approximately 1,700 in the winter and well above that in the summertime. ${ }^{4}$ Just southwest of the reserve is an area used by the military for artillery training, with rounds being fired into the sea. The area can be characterized as a place where several interests: residents, tourists, the military, and nature conservation, result in potential conflicts regarding goals and management. The area is described as unspoiled and will remain unexploited into the future, but at the same time it is also described as being in need of restoration to reverse the effects of human activity. ${ }^{5}$ Since the EU project and the management policies and practices were intimately interwoven by being morally charged by political rationalities, it is necessary to discuss their epistemologies involved in the shaping of the local landscape's socio-natures (Forsyth 2008; Hinchliffe 2002; Hinchliffe and Whatmore 2006; Jorgensen and Tylecote 2007; Swyngedouw 2006; Wilkinson 2012).

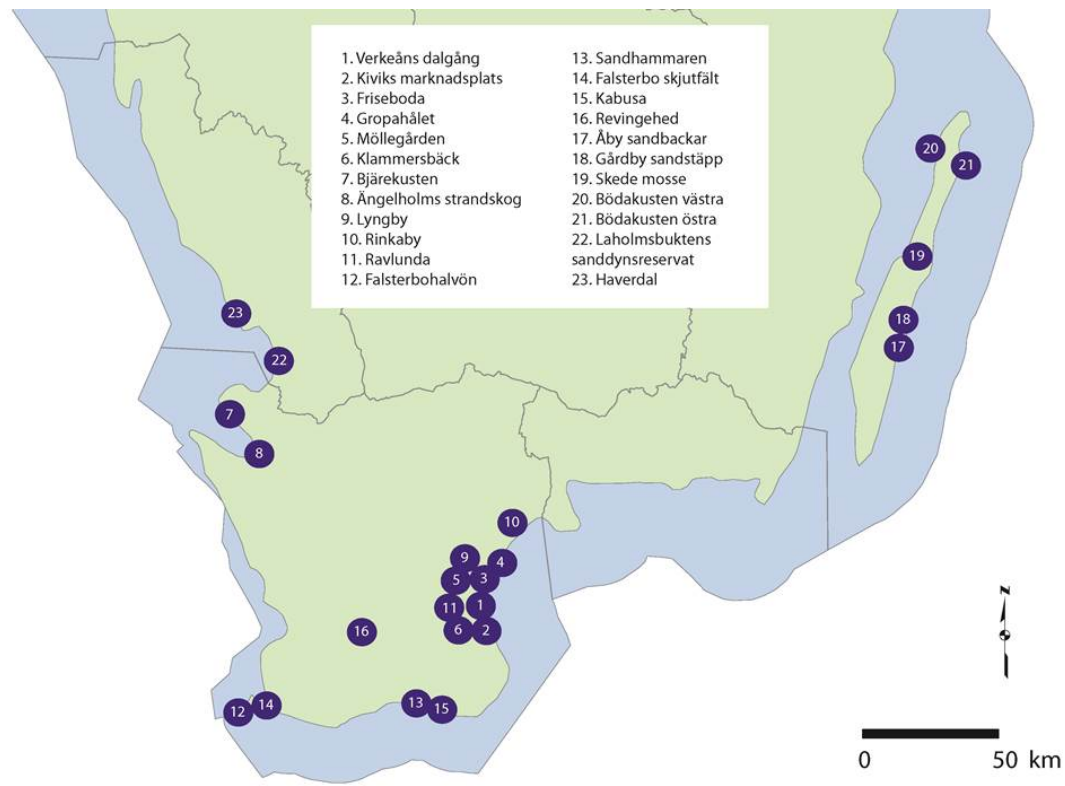

Figure 1: Location map of Natura 2000 sites in Halland, Sweden. Haverdal is no. 23. Source: Sandlife project, archived at http://sandlife.se/?page_id=1726.

\footnotetext{
${ }^{3}$ https://www.lansstyrelsen.se/halland/besoksmal/naturreservat/halmstad/haverdal.html

${ }^{4}$ http://www.regionfakta.com/hallands-lan/geografi/storre-tatorter/

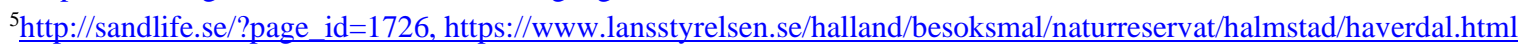




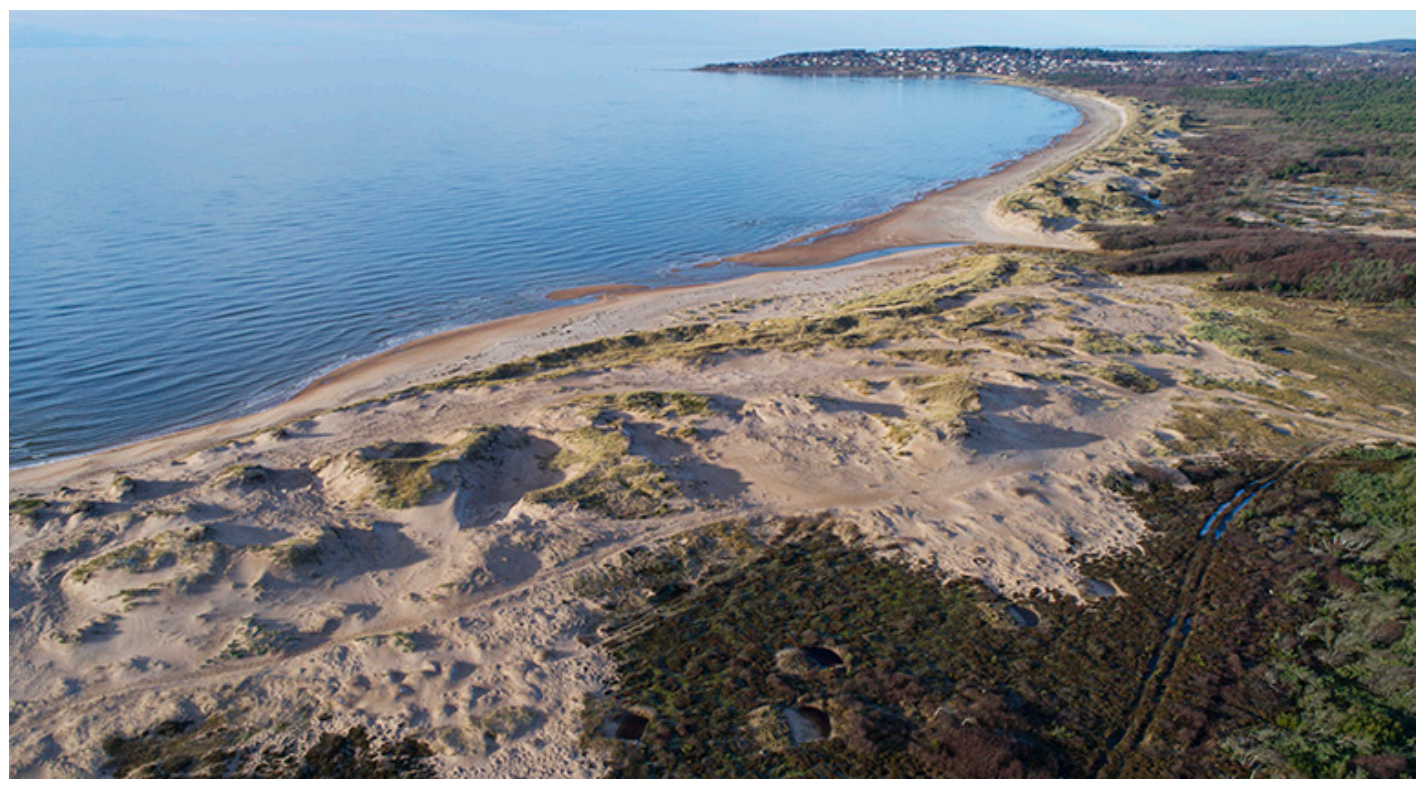

Figure 2: The dune area within the Natura 2000 reserve and the village of Haverdal at the top of the image.

Source: https://www.lansstyrelsen.se/halland/besoksmal/naturreservat/halmstad/haverdal.html

The area has been of concern for regional authorities since the beginning of the twentieth century. Haverdal has a history of drifting coastal sands. Anton Brandberg was given the task of mapping sand drift, which resulted in protection act in the form of a royal decree from 1826 which threatened severe fines if the dune areas were disturbed (Abenius and Larsson 2004: 7; Lantmäteriet 1819). This was to protect economic interests, mainly farmers and residents in the inland who did not want sand blowing in from the coastal dune area. Large efforts were also made during this time by planting pine in order to stop the sand from blowing inland. In the early 1900s tourism began, and the number of summer vacation homes grew (Magnusson-Rading 2012:75). As a result of this, the idea of protection took another turn by the 1950s. This time it was the nature within and nearby the dune area that was in need of protection from the expansion of housing and tourism. The Swedish Society for Nature Conservation decided to buy or exchange land in order to sell it on to the Swedish State. After a parliamentary decision 1973 the area was turned into a nature reserve, which eventually led to the Natura 2000 reserve status (Magnusson-Rading 2012: 78-79). The earlier protective and conservationist measures by planting trees and encouraging children not to play in the dunes, were contested early on by biologists who claimed that these measures would lead to an increase of the size of the dunes and thus make them vulnerable to erosion. The protective measures was said not to pay attention to the dynamics of the area and 'protecting by not doing anything' would in turn affect the life of plants and animals (Abenius and Larsson 2004: 6). Today, the idea is to physically intervene in the landscape through reconstruction with heavy machinery, removal of what are said to be invasive species, and clearance of vast areas of forest near the dunes (CABH 2015).

A specific feature of traditional planning in this landscape is the use of decide-announce-defend (DAD) planning procedures (Breukers 2006: 43). The use of DAD approaches in planning and implementing projects also involves an epistemological and political ecology dimension related to disciplinary background, and disciplinary fostering of social- and natural scientists working in applied disciplines. While applied natural scientists are perhaps most interested in overcoming or circumventing opposition to deliver their management goals, social researchers often focus on exploring competing aims and the knowledge that underpins disputes and participating in support of the disadvantaged, or as in this case, the neglected citizens of the village of Haverdal, who protested for a long time before the project started (Crowley, Hinchliffe, and McDonald 2017). 
The Natura 2000 project SandLife was debated and defended throughout its life up to and including its completion in 2018. It is estimated that about 7,000 people and ten local associations were involved in activities opposing radical change to the landscape, involving the clearing areas of forest and using machines in the dune area (SVT News May 2011, May 2013). Although some changes were made to the original project plan (an early version of the project plan is not available on CABH or SandLife websites anymore), the CABH did not announce decisions until after the authority had enacted them, thus depriving the public of a chance to contest these changes (CABH 2013). One consequence of the restoration and management of the landscape in question is that tensions between the authorities (military, $\mathrm{CABH}$ and the municipality) and the local population, including visitors, have divided the community into those who are positive towards the project and management, and those who are not convinced about its positive outcomes. Another consequence is that the lack of engagement from social scientists or geographers has overemphasized material aspects of the landscape and downplayed social dimensions.

\section{EU and the formation of reified time-spaces of conformity}

The added component of EU project support was used by the authorities in order to reconfigure policies for management of the area, visible in management documents and other documentation of the SandLife EU project. ${ }^{6}$ The management involved a turn from appreciating conservation and morphological features in the landscape towards focusing on biological ones (Abenius and Larsson 2004). The presence of EU funding meant that its projects try to fuse socio-natures into a single time-space system consisting of all types of flows of goods, humans, and representations (Rose and Miller 2010). However, since all types of intentions need to be translated by local authorities, practices and discourses will produce hybrids where traditional governance involving DAD approaches are interwoven with new ideas on management and restoration, where concerned citizens are involved in the restoration process by using participatory methods (Stenseke 2009).

Interest in the dune landscape grew more ambitious and systematic with funding from the EU, leading to greater ambition and more documentation. The emerging narrative suggested planning and restoration need to separate nature, culture, history, and tourism from each other by reifying landscape values into representation of objects. This denies the dynamics inherent in historical processes. Planning rationalities can be seen in one aim (of many) in the EU project SandLife where the restoration aimed explicitly at recreating the landscape of the 1950s and refers to photographs of the dune area taken during that time (CABH 2013). Projecting the past onto contemporary landscapes is called the "colonization of time" (Svanberg 2003), in which "[t]he present determines where, in the object from the past, that object's fore-history and after-history diverge to circumscribe its nucleus" (Benjamin 1999: 476). It functions as a value-based demarcation of spatial belonging (Qvenild 2014). Large EU-financed projects mirror this, aiming to produce lasting effects on a location over time. From a spatial perspective, large projects help to "organize and reorganize popular perceptions of difference within a global economic order" (Curtin 2001: 338). It is presumed that the reshaping of the place to a former condition will make it more authentic with regards to materialities such as plant and insect populations. A consequence of the restoration and management of the landscape is that the EU project justified and legitimized activities within a larger epistemological framework, fixing restoration to a temporal point, and increasing the leverage of goals, but also risking unintended or unforeseen consequences. However, since traditional DAD approaches were used and excluded the local population, it took time and energy to complete the SandLife project and it is still a matter that is difficult to discuss among the people living in Haverdal. In defense of the project, it was argued that restoration through large EU projects such as SandLife is needed as traditional landscapes gradually disappear and that different periods in history need to be integrated into the future demands and needs of society (Antrop 2005).

\footnotetext{
${ }^{6}$ http://sandlife.se/?page_id=24, see also a project from the Netherlands https://www.dw.com/en/saving-the-dynamicecosystems-of-the-dutch-dunes/a-50471813.
} 


\section{Untouched vulnerable nature}

The views of nature and culture in the documents consulted portray a human influence on nature, consistent with ideas from the practice of conservation. To fulfil the purpose of the management plan, it was decided that open sand dunes and moors were to be maintained in order to prevent the overgrowth of invasive species and to benefit endangered species on the International Union for the Conservation of Nature (IUCN) Red List Database that are associated with this environment. ${ }^{7}$ Narratives about the landscape in the documents describing the restoration of the Natura 2000 area (CABH 2013, 2015) emphasize that humans have altered an untouched pristine wilderness, requiring a reversal of human impact and resetting natural processes to a fixed time-space from where it is believed to have been destabilized (see Denevan 2011).

Removing overgrowth, including pines and alien woody plants, is held to benefit the open grass and dry heath areas (CABH 2013, 2015). The land's history is described as one of open heaths, probably used by the local population for thousands of years. Biological values associated with the open sandy soils are said to have long continuity in the landscape, several of the Red Listed species are said to be found on the beach and in the dunes, and the plants and animals in this area are said to have cultural historical value (Ibid). Burning the dry heath was common to improve animal pasture, but overuse of the heaths increased the transportation of sand from the dune area, so Canadian pine was planted to prevent the sand from migrating inland to farming areas. The plan states that an ongoing international responsibility to stop the extinction of species motivates natural restoration programs in Sweden (CABH 2013: 9). An example of such a threatened species is the Tawny Pipit (Anthus campestris), which has rapidly diminished in Halland with the overgrown sand areas and exploitation of the area. The selected Red-Listed species are presented in terms of specific aesthetic objects in a nature referred to as a biological realm, rather than the morphological realm of sand dunes and a beach, or to a complete landscape area.

The dune area was earlier described as sensitive to destructive erosion (Olsson 1974: 8). Today, it is defined as a "dynamic" area, shaped continuously by waves and wind processes. Measures to retain the sand through revegetation and other methods were stopped in the 1980s because the overgrowth of the introduced species. These were previously thought to be synonymous with biological values, but then believed to contribute to the ongoing impoverishment of natural values because "Earlier maintenance of sandy soils focused on measures to stop the migration of sand. During the last 15 years, the knowledge has emerged that more active and dynamic maintenance is needed to conserve native open sandy soils with high nature values" (CABH 2013: 10). At the moment though, a more extensive study of areas south of Halland shows that $12 \%$ of the coast is vulnerable to erosion, especially with rising sea levels that probably will justify other discourses and practices being implemented across the landscape in future (Malmberg-Persson, Nyberg, Ising and Rhode 2016).

Restoration and management plans and the project proposal for SandLife ${ }^{8}$ describe the area as vulnerable and unstable, calling for intervention based on norms, interests and values in which the ideological implications of winners and losers are considered (Blaikie 1985; Swyngedouw 2006). In order to emphasize and strengthen the status of the area, the CABH authority suggested at one point that research in the Natura 2000 area be banned. One early version of the management plan announced that "[w]ithout permission from the local council, conduct of scientific investigations violates the rules" (CABH 2013: 5). The suggestion probably indicates that in the eye of planners, only natural science investigations exists, which would justify such a measure in order to protect the area from disturbance.

With large earth movers removing vegetation in the dune area and reconstructing the former shape and morphology of the dunes, an environmental management approach can develop into what can be called an urbanized, extensive and intensive form of governmental gardening. It displays aesthetic preferences for particular species of plants and animals, defining socio-ecological relations in terms of power (Figure 3, 4) (Davoudi and Mehmood 2010; Evans 2011; Hinchliffe 2002; Hinchliffe and Whatmore 2006; Jorgensen and Tylecote 2007; Swyngedouw 2006; Wilkinson 2012).

\footnotetext{
${ }^{7}$ http://www.iucnredlist.org

${ }^{8}$ http://sandlife.se/?page_id=785
} 


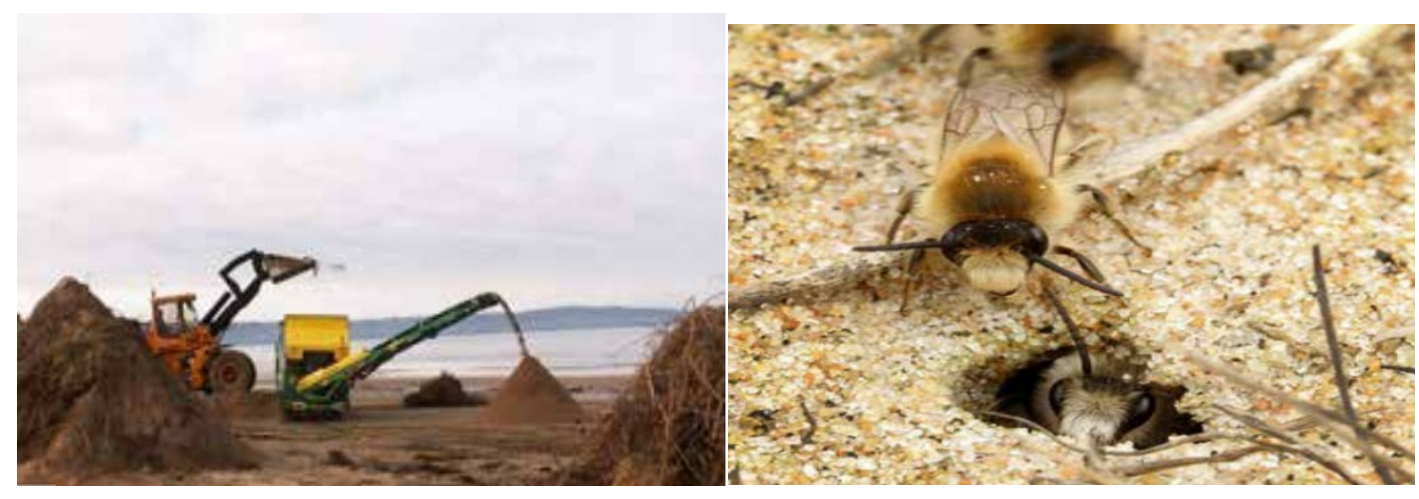

Figure 3: The use of heavy machinery used in order to remove unwanted species in the dunes. Figure 4: Colletes cunicularius or the Spring mining bee is argued to be a threatened species when the ground is covered without active management. Source: https://www.lansstyrelsen.se/download/18.42c2c9ca162f6e008c83179d/1526067830337/Kusth edsblad.pdf

A consequence of the restoration and management of the landscape is that the redefinition of vulnerability, from morphological- towards biological protection allows for up-scaling and leverage of cleansing, burning, extinction, replacing, reordering, and reselecting species that are believed to belong to a particular landscape that is biologically vulnerable and morphologically strong.

\section{Invasive alien species from foreign countries}

Removing species that are deemed to be harmful and blacklisted by the IUCN Council (2000 n.p.) have been key elements of the SandLife project. The intention with these listings is to enable decisions over which species to conserve or protect and which to eradicate (Setten 2017: 31). By contrast, the New Ecology paradigm has challenged the idea of a static biodiversity and places more emphasis on adaptive forms of management that recognize the constant flux of resilience and diversity. But it also includes combatting invasive species, as seen below (Davidson and Williams 2017: 23).

A theme that runs through the documents from the project and management plans is the threat from alien species. The implicit motive for restoring the nature reserve is to correct the human introduction of alien species, and the project is meant to restore the area by clearing away these species. Throughout these texts, invasive alien species are described as being of foreign national origin, and thus not native, and thus not valued aesthetically. The area is referred to now as dead, but it will be recovered through the project. ${ }^{9}$ The objectives of the SandLife project were to:

.... restore, maintain, and improve biodiversity in 23 Natura 2000 areas on sandy soils in southern Sweden. The project will use already developed methods to restore a 'favourable' conservation status to several Natura 2000 habitat types and ensure positive development for species linked to sandy soils. These areas, such as plantations of mountain and black pine, may be transferred to other types ... through restoration action.... Restoration work will include clearance of woodland; creation of bare sand areas; removal of the invasive Japanese rose (Rosa rugosa); management of encroachment; and management of heather. Further contributing activities will include the organization of burning events, the establishment of fire-breaks, and construction of fencing. ${ }^{10}$

\footnotetext{
${ }^{9}$ http://sandlife.se/?page_id=24

${ }^{10}$ http://ec.europa.eu/environment/life/project/Projects/index.cfm?fuseaction=search.dspPage\&n_proj_id=4314\#RM
} 
When descriptions conflate the foreign origins with their function in a geographical context once or twice, it can go unnoticed, but when species are systematically referred to as native to Sweden or alien and foreign, questions arise about the sensitivity towards political discourses involved in planning and executing the project. These descriptions also exclude the possibility of non-human agency, where species do more than being just classifications (Dahlberg 2015; Escobar 1995; 1998; Lorimer 2012; Setten 2017). The result is that charged representations circulate on social media, and there they tend to be simplified and their values extrapolated. For example, a letter from the CABH published on Facebook explained that the characteristic "troll pines":

.... have been saved, which are the wind-twisted Swedish pine (Pinus sylvestris) .... Over time the plan is to eliminate all planted pine, including the North American Contor Pine (Pinus contorta), to allow Swedish fauna and flora to re-establish themselves. The Swedish nature reserves are for the long-term protection of a piece of valuable Swedish nature. (Letter from the RCH published on Facebook, author's translation)

We are engaged in a narrative in which the foreign species were mistakenly placed in the area, and now it is the time to correct this. The narrative also reinforces the shift in aesthetic appreciation from morphology to biology and towards increased appreciation of the native flora and fauna. The epistemology and ontology characterizing this type of representation in texts do not handle the potential ideological and aesthetic values they promote, by repeatedly contrasting the alien and the native in terms of nationality (Simberloff 2003; Van Wilgen 2012). The intertwining of aesthetic values with nationalistic and ethnic elements involve the practitioners and scientist's definition of a subject-object relation, in which no other elements are allowed to disturb the landscape than those agreed by the staff who inspect and control nature according to natural science or landscape engineering ideals (Santyana 1986).

From a social science perspective, however, it seems crucial to understand the consequences of the insensitive subject-object relation and how those consequences may shape representations, with a focus on documents produced in landscape restoration and management. In a contemporary setting existing in many countries over the world today where nationalism and marginalization of ethnic groups are common, insensitive ways of communication in official planning documents and in other representations may contribute to colonial and xenophobic views of alien species in native environments (Olwig 2003). There are also examples of natural scientists who, worried about the penetration of alien species, often appear to be unaware of parallels between their discourse and those of racists and national chauvinists. Such concerns are often expressed regarding fear of bio-invasion and biotic intermixing (Coates 2003). ${ }^{11}$ Writers like Gröning and Woschke-Bulmahn (2004) go so far as using phrases like "plant racism", "plant Nazis", and "species cleansing", with clear connotations of xenophobia and racism (Simberloff 2003: 179; van Wilgen 2012). Although the practical value of the native versus alien species dichotomy in conservation is declining and even becoming counterproductive, it is still considered a core guiding principle (Carrol 2011; Davis et al. 2011; Fleishman et al. 2011). When a species' foreign origin is emphasized it becomes a representation of the "other" in terms of nationality, familiarity, and alien heritage, which in turn may be confused with aesthetic features promoted by authorities.

The consequence of not being sensitive to the political aspects of restoration and management is that nature is charged with values of national belonging justified by DAD-approaches. The shift from morphological to biological aesthetics, in which planners easily can ignore their intentions and ideologies, may result in an institutionalized protection of nature from a nature-justice moral position.

\section{The Days of the Sand and scaling down to bio-diversity}

SandLife claimed to have arranged an impressive 131 meetings with specific groups and individuals, landowners, and residents in the area of the project. Signs were put up, and 12 outdoor museums were built where information about the sandy soils could be found. They also claimed to follow the rules and regulations

\footnotetext{
${ }^{11}$ See other articles in the same issue of Landscape Research from 2003.
} 
of national authorities for guidance in assessing sand dunes and heaths and to have arranged 65 guided field tours to show natural features and to inform the public about the measures taken in the project.

I attended one of these tours, "The Days of the Sand", on May the 9th, 2015. ${ }^{12}$ On that occasion, we were assumed to be a group of people interested in biology as if we were taking part in a school class excursion, and two themes were prepared in these presentations: biodiversity and sand dune management. During this one-day excursion, a presentation of the landscape was prepared by using sticks and flowers as markers. The group was led toward a spot where everyone's attention was drawn to a small flower next to a stick. Everyone leans forward to see. One person does not pay attention to where she puts her feet and accidentally tramples one of the rare flowers. No one notices, and nothing is said about it:

You must all be happy to see a Dwarf dandelion here on this typical sand moorland [pointing to a 20 square meter large area next to the parking space]! However, you all have to be aware of where you put your feet since this is nature reserve. (Excursion leader)

The audience was interested and knew quite a bit about dune processes and biology. The excursion leader asked questions, and the audience replied with correct answers. The excursion leader challenges the group about dune processes on a few occasions: "What type of plant is this?" he asks while pointing to a specific grass on the small representative surface. "Lyme grass", someone in the crowd, replies quickly. "And what is the name of the other grass that you can see at the top of the dunes ahead?" he asks but gets no answer. "It is Marram", he says:

Marram and Lyme grasses are invasive species that arrived in the late 1800s. They were very popular and planted here to avoid erosion and sand drift. When I was young, it was not allowed for anyone to jump on the dunes, and it is. Therefore, we have Rugosa roses everywhere here today. (Excursion leader)

Narratives in documents and practices such as excursions and communication refer to both the privileged and the knowledgeable individuals and groups as well as to aesthetic features regarding the landscape. The landscape restoration and management project involve specific relations between the politics of aesthetics and biodiversity concerning invasive alien plant species. The problem with natural science or a practitioner's focus on material objects in the landscape is that particular forms of design are believed to influence how humans interact and behave, and therefore how these objects should be defined aesthetically, although humans will not always align with these intended values.

\section{Bio knowledge capital}

The excursion leader, a representative of the $\mathrm{CABH}$, was dressed in durable clothes especially suitable for being in nature, with binoculars and a magnifying glass around his neck. He drew the crowd's attention to a half-excavated thorny root system with a few green leaves:

And here you can pull up Rosa rugosa. It is an invasive species from Russia. They are imported by humans and are introduced in other ways. You know, people want them in their gardens, and they spread. They come from a different part of the world. We take out Heracleum mantegazzianum [giant hogweed] and Rosa rugosa because they are dominant and they arrived late. The invasive species push out the species that belong here, not because they are from Russia, but because they are dominant [laughs]. Joking aside; they are being removed because our main purpose is to reclaim the sandy moorland. (Excursion leader)

\footnotetext{
12 http://sandlife.se/?tribe_events=sandens-dagar-i-halland
} 
The guide asks the driver of an excavator to remove some Japanese rose to illustrate how they begin by removing the plant and roots with one shovel, then use another to expose the lower layers of sand. He explains that the sand is arranged in different piles according to the type of material. The roots are then milled and used as biofuel, while the sand is returned in the proper order to the hole made when the plant is completely removed. He jumps down into the pit and shows another Japanese rose root system to the crowd:

As you can see the root system is impressive, with long and extensive roots that find their way down in the sand in search of nutrition and water. The work of removing the Rosa rugosa has to be done continuously to work. That means we need to come back, again and again, to remove them permanently, it is not done at once.... What we are doing now is the main job, and the plan is to return and maintain the situation by burning the area, but as you can see sprouts are coming on already over there [pointing a few meters away from the pit]. As you have seen, we have arranged firebreaks at the border of the area, and if you are out walking and do not know where to go, you can always walk along these firebreaks to keep free from vegetation. That would perhaps save you some tax money. [laughs] (excursion leader)

The actor with bio-knowledge capital who could appreciate the aesthetics of nature was appropriately dressed in clothes that can endure close contact with nature, even if he has come from his public office at the CABH. Our excursion leader was equipped with instruments that allow him to come closer to objects in the sand and he mastered the terminology and shared it with others in the group at the same time as he challenged their knowledge and joked about foreign species. Finally, he drew a line between the alien and the familiar by defining what measures are needed in the area to protect the small and vulnerable species that can only be viewed through binoculars or a magnifier.

\section{Nature justice}

Narratives, or storylines, support a discourse by targeting and describing the visitors and species that are appreciated, and the ones who are not appreciated by being non-native or by destabilizing a landscape. This process, ionically, expresses unequal power relations in which humans are seen as disturbing the landscape, so their movements must be controlled and even excluded to maintain an aesthetics of proper landscape restoration and management. This is activist nature-justice aesthetic value which is used to justify control and exclusion. The project and management plans narrate an ideological nature-justice aesthetic that has its counterpart in the social justice stance in social sciences (Harvey 1992). Nature-justice activists fight to protect species that are vulnerable, rare, threatened by humans, and in great need of support:

Many of the species that live in sandy soils are vulnerable to competition. This means that their opportunities to survive decrease if bushes and heath become too dominant.... The goal of maintaining open heaths is to compose a mosaic of the successive phases of the heath, from early stages of bare soil and newly burned areas, to areas with the sturdy heath and crowberries.... It is positive if there are, interspersed in the heath mosaic or its vicinity, also more bushy and treed areas, with open sunny areas and flowering bushes of, for instance, wild roses, sallow, and Rowan, which benefit a broad range of insects, for instance, many butterflies, wild bees, and hoverflies, who need both open and closed areas during their life cycles. (CABH 2013: 11-12)

Such detailed representations and constructions of a nature-justice aesthetic work as a strong argument to justify excluding humans, minimizing transparency, and ignoring resistance to landscape projects. In narratives of a nature-justice aesthetic, values are constructed as regimes of ecological truth that can ignore inconsistencies by noting that people "[t]read on paths, as horse riding and pasture are also important factors that can contribute to disturbances in the thin sand" (CABH 2013: 11). Contradictions are never far away, however. For hundreds of years, the dominant use of the reserve land was as pasture for cattle and horses. 
These species are considered better than sheep (CABH 2013), and their pasturing has been argued to be effective in enriching the flora and thereby a range of insects and birds (Ibid). The management plan must therefore balance between protecting the landscape from human and animal activities that may affect the thin sand, and, at the same time allow for heavy machines to drive through the dunes and dig sand.

The shift from a morphological aesthetic to biological appreciation requires new and drastically different approaches from the attitude that the former sand dunes needed protection from birds and bugs: "Methods used are rather radical in order to increase the proportion of open sand: ...pulling up plants by the roots, digging up Rosa rugosa, clearing, forage, burning and pasture" (CABH 2013: 11). A consequence of the shift from morphology to biology result in new narratives of restoration and management which are political, aesthetic, and discursive, and they tend not to pay attention to inconsistencies when shifting the focus from morphology to biology so long as they justify epistemological anchorage in nature-justice related activities. The construction of nature does not stop at representations of species and the clearing the area of unvalued plant species to create the desired aesthetic values; it also includes a wish to reintroduce animals believed to have inhabited the area earlier in its history:

The reintroduction of threatened species in sandy soils that were in the area earlier or are from the wider area may be considered when sufficient environments have been restored. The Matter Jack toad, Holly, and the Dune Tiger beetle are examples of species that may be considered.

(CABH 2013: 16)

\section{Conclusion}

The study has illustrated how contextual narratives, discourses, representations, technologies and project funding involved in landscape conservation and restoration can influence the conduct of nature conservation practices. In terms of political ecology, the influence of powerful arguments for conservation, outside the local area and linked to EU landscape restoration requirements, are illustrated by the requirements of management plans and the former EU funded SandLife project to recreate past dune environments, devoid of invasive species. The shift in focus from preserving the morphological features of the Natura 2000 reserve towards its biological elements reveals that traditional discourses and practices based on DAD approaches remained strong as the basis for landscape management and restoration in recent years. The rationales underpinning ideologies, practices and discourses are described in terms of aesthetic values that are biocentric, rather than recognizing the complexity in power relations, agency and the co-construction of nature that political ecologists and others identify (eg. Benjaminsen and Robbins 2015; Benjaminsen and Svarstad 2019; Castree 2005; Castree and Braun 2001; Dahlberg 2015; Nightingale 2014; Robbins 2012; Robbins et al. 2015). Nature is viewed as unstable and in acute need of protection by the urban authorities. Protective works try to order heterogeneous socio-ecological processes and socio-natures, again in ways that have been discussed elsewhere (Davoudi and Mehmood 2010; Evans 2011; Hinchliffe 2002; Hinchliffe and Whatmore 2006; Jorgensen and Tylecote 2007; Leino, Karppi, and Jokinen 2017; Swyngedouw 2006; Wilkinson 2012).

At the core of the dune restoration project, we find a planning tradition characterized by DAD procedures in which risks are handled by avoiding, resisting, and circumventing the involvement of people living in the area (Breukers 2006: 43). One important reason for the problematic process in the SandLife project and the reorientation of focus from morphology to biology can be found in how the competencies in planning were composed. The CABH of Halland is a small unit in a national context. The project and the staff at this council draw most of their competencies from the natural sciences or they work as practitioners. Traditional views on planning, such as DAD approaches, are accepted in order to deliver management expectations, overlooking or minimizing competing aims and sources of dispute (Crowley, Hinchliffe, and McDonald 2017). The EU project provided further justification and funding for large scale conservation based on biocentric ideals, rather than on local knowledge and expectations. Cleansing, burning, replacing, reordering, and reselecting species could occur, in the belief that a particular landscape that is biologically vulnerable and morphologically strong was being created. There was an institutionalized protection of nature justified from a nature-justice moral position and epistemological anchorage. Although it is beyond the scope of this article, 
tensions between the authorities (military, RCH and the municipality) and the local population, including visitors, have divided the local community - a result of downplaying the social dimensions of dune landscape restoration. A recommendation is that landscape restoration and management have to compose projects and practices so that they include wider competence areas than just natural science in order to handle the political ecology of nature.

\section{References}

Abenius, J. and K. Larsson. 2004. Gaddsteklar och andra insekter i halländska sanddynsreservat [Aculeata and other insects in sand dune reserves in Halland]. Information från Länsstyrelsen (retrived 15/7/2019) https://www.diva-portal.org/smash/get/diva2:863304/FULLTEXT01.pdf

Antrop, M. 2005. Why landscapes of the past are important for the future. Landscape and Urban Planning, 70(1-2): 21-34. doi:10.1016/j.landurbplan.2003.10.002

Benjamin, W. 1999. The Arcades project. Tiedemann, R. (ed.), Eiland, H. and McLaughlin, K. (Trans.) Cambridge: Harvard University Press.

Benjaminsen, T.A. and P. Robbins. 2015. Nordic political ecologies. Norsk Geografisk Tidsskrift - Norwegian Journal of Geography 69(4): 191-196. doi:10.1080/00291951.2015.1059879

Benjaminsen, T.A. and H. Svarstad. 2019. Political ecology. In B. Fath (ed.). Encyclopedia of ecology. Elsevier. Pp. 391-396.

Blaikie, P.M. 1985. The political economy of soil erosion in developing countries. London: Longman.

Breukers, S. 2006. Changing institutional landscapes for implementing wind power: a geographical comparison of institutional capacity building: The Netherlands, England and North Rhine-Westphalia. Amsterdam: Amsterdam University Press.

CABH. 2013. See Länsstyrelsen 2013.

CABH. 2015. See Länsstyrelsen 2015.

Castree, N. 2005. Nature. London: Routledge.

Castree, N. and B. Braun, B. 2001 (eds.). Social nature: theory practice and politics. Oxford: Blackwell.

Carroll, S.P. 2011. Conciliation biology: the eco-evolutionary management of permanently invaded biotic systems. Evolutionary Applications 4(2): 184-199.

Crowley, S.L., S. Hinchliffe and R.A. McDonald. 2017. Invasive species management will benefit from social impact assessment. Journal of Applied Ecology 54: 351e357.

Curtin, M. 2001. Organizing difference on global TV: television history and cultural geography. In G.R. Edgerton and P C. Rollins (eds.). Television histories: shaping collective memory in the media age. Lexington: University Press of Kentucky. Pp. 333-356.

Dahlberg, A. 2015. Categories are all around us: Towards more porous, flexible, and negotiable boundaries in conservation-production landscapes. Norsk Geografisk Tidsskrift - Norwegian Journal of Geography 69(4): 207-218. doi:10.1080/00291951.2015.1060258

Davidson, A. and S. Williamson. 2017. The outside within: the shifting ontological practice of the environment in Australia. In L. Head, K. Saltzman, G. Setten and M. Stenseke. (eds). Nature, temporality and environmental management: Scandinavian and Australian perspectives on people and landscapes. London: Routledge. Pp. 15-29.

Davis, M.A., M.K. Chew, R.J. Hobbs, A.E. Lugo, J.J. Ewel, G.J. Vermeij, J.H. Brown, M.L. Rosenzweig, M.R. Gardener, S.P. Carroll, K. Thompson, S.T.A. Picket, J.C.Stromberg, P. Del Tredici, K.N. Suding, J.G. Ehrenfeld, J.P. Grime, J. Mascaro and J.C. Briggs. 2011. Don't judge species on their origins. Nature 474: 153-154. https://doi.org/10.1038/474153a

Davoudi, J.C. and A. Mehmood (eds.). 2010. Planning for climate change: strategies for mitigation and adaptation for spatial planners. London: Earthscan. Pp. 7-18.

DeLyser, D., S. Herbert, S. Aitken, M. Crang and L. McDowell. (eds.). 2009. The SAGE handbook of qualitative geography. Thousand Oaks: Sage. 
Denevan, W.M. 2011. The "Pristine Myth" revisited. Geographical Review 101(4): 576-591. doi:10.1111/j.1931-0846.2011.00118.x

Escobar, A. 1995. Encountering development: the making and unmaking of the third world. Princeton, NJ: Princeton University Press.

Escobar, A. 1998. Whose knowledge, whose nature? Biodiversity, conservation, and the political ecology of social movements. Journal of Political Ecology 5(1): 53-82.

Evans, J.P. 2011. Resilience, ecology and adaptation in the experimental city. Transactions of the Institute of British Geographers 36(2): 223-237.

Fleishman, E., D.E. Blockstein, J.A. Hall, M.B. Mascia, M.A. Rudd, J.M. Scott, W.J. Sutherland, A.M. Bartuska, A.G. Brown, C.A. Christen, J.P. Clement, D. Dellasala, C.S Duke, M. Eaton, S.J. Fiske, H. Gosnell, J. C. Haney, M. Hutchins, M. L. Klein, J. Marquesee, B. R. Noon, J.R. Nordgren, P.M. Orbuch, J. Powell, S.P Quarles, K.A. Saterson, C.C. Savitt, B.A. Stein, M. S. Webster, A. Vedder. 2011. Top 40 priorities for science to inform US conservation and management policy. BioScience 61: 290-300.

Forsyth, T.J. 2008. Political ecology and the epistemology of social justice. Geoforum 39(2): 756-764.

Gill, R. 2000. Discourse analysis. Thousand Oaks: Sage.

Ginn, F. and D. Demeritt. 2014. Nature: a contested concept. In Clifford, N., S. Holloway, S.P. Rice and G. Valentine (eds). Key concepts in geography. Thousand Oaks: Sage. Pp. 300-311.

Gröning, G. and J. Woschke-Bulmahn. 2004. The native plant enthusiasm: ecological panacea or xenophobia? Landscape Research 28: 75-88.

Hajer, M. and W. Versteeg. 2005. A decade of discourse analysis of environmental politics: achievements, challenges, perspectives. Journal of Environmental Policy and Planning 7(3): 175-184. doi:10.1080/15239080500339646

Hajer, M. 1995. The politics of environmental discourse. Oxford: Clarendon.

Hajer, M. 2001. The need to zoom out: understanding planning processes in a post-corporatist society. In Madinapour. A., A. Hull and P. Healey (eds). The governance of place: space and planning processes. Aldershot: Ashgate. Pp.178-202.

Harvey, D. 1992. Social justice, postmodernism and the city. International Journal of Urban and Regional Research 16(4): 588-601. doi:10.1111/j.1468-2427.1992.tb00198.x

Harvey, D. 1996. Justice, nature and the geography of difference. Cambridge, MA: Blackwell.

Head, L., K. Saltzman, G. Setten and M. Stenseke (eds.). 2017. Nature, temporality and environmental management: Scandinavian and Australian perspectives on people and landscapes. London: Routledge.

Hinchliffe, S. 2002. Inhabiting - landscapes and nature. In Anderson, K., M. Domosh, S. Pile and N. Thrift. (eds.). Handbook of cultural geography. London: Sage. Pp. 207-225.

Hinchliffe, S. and S. Whatmore. 2006. Living cities: towards a politics of conviviality. Science as Culture 15(2): 123-138. doi:10.1080/09505430600707988

Hsieh, H.F. and S.E. Shannon. 2005. Three approaches to qualitative content analysis. Qualitative Health Research 15(9): 1277-1288. doi:10.1177/1049732305276687

IUCN Council. 2000. Guidelines for the prevention of biodiversity loss cased by invasive alien species. Gland, Switzerland: International Union for Conservation of Nature.

Jonasson, M. 2000. The creation of places in traffic through performative action. PhD dissertation. Department of Human and Economic Geography, series B No. 98. Göteborg: Göteborgs University.

Jorgensen, A. and M. Tylecote. 2007. Ambivalent landscapes—wilderness in the urban interstices. Landscape Research 32(4): 443-462. doi:10.1080/01426390701449802

Lantmäteriet. 1819. Flygsandsfälten i Hallands län. [Sand drift fields in Halland] Lantmäteriets arkiv. (Retrieved 15/7/2019) https://arkivkopia.se/sak/lms-M26

Leino, H., I. Karppi and A. Jokinen. 2017. It's all about the birds! Non-human actors' situational power in creating conditions for human engagement. Planning Theory 16: 133-149. doi:10.1177/1473095215617985 
Lorimer, J. 2012. Multinatural geographies for the Anthropocene. Progress in Human Geography 36(5): 593612. doi:10.1177/0309132511435352

Low. T. 2001. From ecology to politics: the human side of alien invasions. In J.A. McNeely (ed.). The great reshuffling: human dimensions of invasive alien species. Gland, Switzerland: International Union for Conservation of Nature. Pp. 35-42.

Low, T. 2002. The new nature: winners and losers in the wild Australia. Melbourne: Penguin.

Länsstyrelsen [County Administrative Board, CAB]. 2013. Skötselplan för naturreservatet i Haverdal. Dnr 511-4721-12. [Maintenance plan for the nature reserve in Haverdal]. Retrieved 26/2/2020 https://www.lansstyrelsen.se/download/18.6f456f1162f6d08f5e99cc/1526068043675/Sk\%C3\%B6tsel plan\%20f\%C3\%B6r\%20naturreservatet\%20Haverdal.pdf

Länsstyrelsen [County Administrative Board, CAB]. 2015. Restoration plan for Nature-2000 area Haverdal SE0510020 in Halmstad, county of Halland. Dnr: 512-465-13.

Länsstyrelsen [County Administrative Board, CAB] n.d. Hallands sandkust - en plats för både människa och natur [The sand coast of Halland - a place for both human and nature]. Retrieved 28/2/2020 from https://www.lansstyrelsen.se/download/18.42c2c9ca162f6e008c83179d/1526067830337/Kusthedsbla d.pdf

Magnusson-Rading, I. 2012. Haver du sett Haverdal [Have you seen Haverdal]. Halmstad: Bull Graphics.

Malmberg-Persson, M., J. Nyberg, J. Ising, J. and L. Rodhe. 2016. Skånes känsliga stränder erosionsförhållanden och geologi för samhällsplanering. [The vulnerable beaches of Skåne - Places of erosion and geology for planning]. SGU-rapport 2016: 17. Geological survey of Sweden. Retrieved 28/2/2020. http://resource.sgu.se/produkter/sgurapp/s1617-rapport.pdf

Nightingale, A.J. 2014. Nature-society. In Lee, R., N. Castree, R. Kitchin, V. Lawson, A. Paasi, C. Philo, S. Radcliffe, S.M. Roberts and C.W.J. Withers (eds.). The SAGE Handbook of Human Geography. 2 Volume Set. London: Sage. Pp. 120-147.

Olsson, H. 1974. Studies on South Swedish sand vegetation. Doctoral dissertation. Acta Phytogeographica Suecia 60. Uppsala: Svenska växtgeografiska sällskapet.

Olwig, K.R. 2002. Landscape, nature, and the body politic: from Britain's renaissance to America's new world. Madison, WI: University of Wisconsin Press.

Olwig, K.R. 2003. Natives and aliens in the national landscape. Landscape Research 28: 61-74.

Proctor, J. 1998. Ethics in geography: giving moral form to the geographical imagination. Area 30: 8-18.

Qvenild, M. 2014. Wanted and unwanted nature: landscape development at Fornebu, Norway. Journal of Environment and Planning 16(2): 183-200.

Qvenild, M. and G. Setten. 2019. Locating value in the Anthropocene: baselines and the contested nature of invasive plants. In Hoskins, G. and S. Saville (eds.). Locating value: theory, application and critique. Oxford: Routledge. Pp. 118-128.

Regionfakta [Regional facts]. 2020. Population in Halmstad centers 1980-2015. http://www.regionfakta.com/hallands-lan/geografi/storre-tatorter/

Robbins, P. 2012. Political ecology: a critical introduction. Second Edition. Chichester, UK: Wiley.

Robbins, P., A. Chhatre and K. Karanth. 2015. Political ecology of commodity agroforests and tropical biodiversity. Conservation Letters 8(2): 77-85. doi:10.1111/conl.12169

Rose, G. 2007. Visual methodologies: an introduction to the interpretation of visual materials. London: Sage.

Rose, N. and P. Miller. 2010. Political power beyond the State: problematics of government. The British Journal of Sociology 61: 271-303. doi:10.1111/j.1468-4446.2009.01247.x

Sandberg, M and S. Jakobsson. 2018. Trees are all around us: farmers' management of wood pastures in the light of a controversial policy. Journal of Environmental Management 212: 228-235. https://doi.org/10.1016/j.jenvman.2018.02.004.

SandLife 2012. Restoration of habitats on sandy soils in southern Sweden. LIFE11 NAT/SE/000849. Retrieved 21/11/2019 11-21 from 
http://ec.europa.eu/environment/life/project/Projects/index.cfm?fuseaction=search.dspPage\&n_proj_i $\mathrm{d}=4314$

SandLife. n.d. Welcome to Sand Life. Website. Retrieved 28/2/2020 from http://sandlife.se/?page_id=785

Santayana, G. 1896 [1961]. The sense of beauty. New York: Collier.

Setten, G. 2017. Landscape, temporality and responsibility: making conceptual connections through alien invasive species. In Head, L., K. Saltzman, G. Setten and M. Stenseke (eds). Nature, temporality and environmental management: Scandinavian and Australian perspectives on people and landscapes. London: Routledge. Pp. 30-45.

Simberloff, D. 2003. Confronting introduced species: a form of xenophobia? Biological Invasions 5: $179-192$. https://doi.org/10.1023/a:1026164419010

Smith, D. 2000. Moral geographies: ethics in a world of difference. Edinburgh: Edinburgh University Press.

Stenseke, M. 2009. Local participation in cultural landscape maintenance: lessons from Sweden. Land Use Policy 26: 214-223. doi:10.1016/j.landusepol.2008.01.005

Svanberg, F. 2003. Decolonizing the Viking Age. Stockholm: Almqvist and Wiksell.

SVT News. 2011. Protests against clearance. May 11. https://www.svt.se/nyheter/lokalt/halland/protester-motavverkning

SVT News. 2013. Decision about the nature reserve in Haverdal is close. May. 17. https://www.svt.se/nyheter/lokalt/halland/beslut-om-haverdals-naturreservat-nar

Swyngedouw, E. 2006. Circulations and metabolisms: (hybrid) natures and (cyborg) cities. Science as Culture 15: 105-121. doi:10.1080/09505430600707970

The IUCN Red List of Threatened Species. 2019. Retrieved 21/11/2019 from http://www.iucnredlist.org/

Van Wilgen, B.W. 2012. Evidence, perceptions, and trade-offs associated with invasive alien plant control in the Table Mountain National Park, South Africa. Ecology and Society 17(2).

Widgren, M. 2015. Linking Nordic landscape geography and political ecology. Norsk Geografisk Tidsskrift Norwegian Journal of Geography 69(4): 197-206. doi:10.1080/00291951.2015.1062797

Wilkinson, C. 2012. Social-ecological resilience: insights and issues for planning theory. Planning Theory 11(2): 148-169. doi:10.1177/1473095211426274

Wästfelt, A., K. Saltzman, E. Gräslund Berg and A. Dahlberg. 2012. Landscape care paradoxes: Swedish landscape care arrangements in a European context. Geoforum 43: 1171-1181. 